\title{
Transatlantica
}

Revue d'études américaines. American Studies Journal

Revisiting the Gilded Age / Littérature et philosophie

\section{African American Street Lit': old, new, or better (?) tricks?}

Cécile Cottenet

\section{OpenEdition}

1 Journals

\section{Édition électronique}

URL : https://journals.openedition.org/transatlantica/6456

DOI : $10.4000 /$ transatlantica.6456

ISSN : $1765-2766$

Éditeur

Association française d'Etudes Américaines (AFEA)

Référence électronique

Cécile Cottenet, «African American Street Lit': old, new, or better (?) tricks? », Transatlantica [En ligne], 1 | 2013, mis en ligne le 13 février 2014, consulté le 31 janvier 2023. URL : http:// journals.openedition.org/transatlantica/6456 ; DOI : https://doi.org/10.4000/transatlantica.6456

Ce document a été généré automatiquement le 31 janvier 2023.

\section{(c) (i) (9)}

Creative Commons - Attribution - Pas d'Utilisation Commerciale - Pas de Modification 4.0 International - CC BY-NC-ND 4.0

https://creativecommons.org/licenses/by-nc-nd/4.0/ 


\title{
African American Street Lit': old, new, or better (?) tricks?
}

\author{
Cécile Cottenet
}

\section{Introduction}

1 African American street lit' emerged in the United States in the mid-1990s, gaining prominence with the triumph of rapper and activist Sister Souljah's best-seller The Coldest Winter Ever (1999) that reportedly sold one million copies in a mere few months. ${ }^{1}$ This field of fiction has since expanded to such an extent that specific imprints devoted to the publishing of texts authored by African American writers depicting gangsta life in urban ghettos have sprouted in mainstream publishing. These books contribute more globally to a "black revival" in African American publishing, alongside what renowned scholar Henry Louis Gates clearly identified in 1997 as a fourth African American cultural renaissance-while literary and general press observers spotted a growth in the number of titles and an increase in consumer interest in black-oriented books (Gates, 1997). Along with these fiction titles, popular self-published books also flourished, as part of a publishing subculture specializing in romance, erotica or general fiction. A writer for the Washington Post wittingly defined street lit', also known as urban fiction, in these words:

The telltale signs usually include a shut-your-mouth title, straightforward sentences, vast amounts of drugs, sex and rap music and varying degrees of crime and punishment. An exemplary tale is a mixture of foul language, flying bullets, fast cars, a flood of drugs, fallen angels and high-priced frippery. It venerates gram over grammar, sin over syntax, excess over success. (Weeks, 2004)

Gritty content aside, the publication histories of these books offer thought-provoking if not fascinating tales of agency and empowerment, involving an ethnic group who, as late as the 2000s, still experienced difficulty finding entry into publishing, either as writers or publishers. Cautiously standing on the edge of cultural relativity, I propose to explore the street lit' phenomenon by focusing on the producers and its publication, rather than on its reception. While the question of the "legitimacy" of the object cannot 
escape interrogation, this issue will be suspended until the conclusion, and I will define the genre, for general purposes, as popular fiction. This essay will thus attempt to show that contemporary African American urban fiction, while innovative, is not entirely novel, especially regarding the distribution and marketing techniques used by its creators. After placing the genre in a long tradition of literature "from below," I wish to demonstrate that, while the publication, promotion and distribution of these books benefit from the latest technology, they are also grounded in a specifically African American book market where the concept of agency-indeed, its "DIY" quality-and reliance on community hark back to the XIX ${ }^{\text {th }}$ century.

\section{Traditions and ancestors "from below"}

3 In the XIX ${ }^{\text {th }}$ century the phrase "street literature" was used to refer to an ephemeral penny literature often printed as broadsides, and targeted at the common man. Its topics ranged from crime to religion, and courtship, sometimes bordering on soft pornography. Interestingly, the name "street literature" then referred to the locus where it was sold by peddlars and rogues, in quite a similar manner to the ways in which contemporary American street lit' is sold (Collison, 1973; Shepard, 1973). One line of ancestry can indeed be traced to the mass of criminal biographies collected in England in the XVII ${ }^{\text {th }}$ and XVIII ${ }^{\text {th }}$ centuries by the Ordinary of the Old Bailey, and later used as bases for criminal fiction magnificently so in Daniel Defoe's emblematic Moll Flanders (1722). Ultimately, from the point of view of today's producers, and regarding its moralistic quality, "urban fiction" is not very far removed from contemporary American gang memoirs that emerged in the wake of the Rodney King riots of 1992, written in prison by African American and Latino gang members and published as criminal confessions. ${ }^{2}$ Like these first-hand accounts of gang experience and violent subculture, urban fiction also tends to create a taste for "black ghetto realness". Many street lit' authors have served prison sentences, and like Malcolm X, discovered and acquired their writing skills in jail. As Shannon Holmes recounts in the introduction to his novel, Never Go Home Again, "Writing came to me at the loneliest time of my life, while I was in prison, during those long, repetitive days and cold nights locked in a cell. At times it gave me a direction when my mind wandered aimlessly. It gave me hope for the future" (Holmes, 2004, 2).

Yet, one needs to look to more recent times for the unanimously claimed ancestors, Donald Goines and Iceberg Slim, author of the cultish Pimp. ${ }^{3}$ Paying tribute to these glorified "gentlemen" without whom "some [...] would still be working nine to fives," street lit' author K'wan Foye reminded his readers in the acknowledgements to the 2005 edition of Hoodlum that Goines and Slim are "gone but not forgotten." ${ }^{4}$ Vickie Stringer also paid homage to Goines in her introduction to Let That be The Reason (2002). Urban fiction's more direct fictional connection is indeed with these 1970s superstar black writers. The semi-autobiographical fiction of these two former pimps and addicts, published by the Los Angeles mass-market paperback publisher Holloway House, greatly contributed to the stereotyping of African Americans, in keeping with the blaxploitation of the era. ${ }^{5}$ The world depicted in this fiction, the underworld of $1970 \mathrm{~s}$ America, peopled with drug kingpins, addicts, convicts, prostitutes and pimps, is just one step away from the ghetto life and "gangsta" mores found in contemporary urban fiction. Incidentally, the origins of the contemporary boom in street lit' coincided in 
the mid 1990s with the revival of black pulp fiction from the 1950s and the 1970s, as exemplified by the launching of the W.W. Norton series, Old School Books.

Themes, characters and content, to say nothing of style, qualify street lit' as fiction "from below." Poor editing, in the case of self-published novels, adds another grammatical characteristic: Vickie Stringer's self-published novels feature problematic spelling, syntax and punctuation, which, even with the greatest magnanimity, can hardly be considered linguistic innovations. The common social and racial origins of the authors-notwithstanding occasional Hispanic authors-their shared experience of the trials and hardships of criminal life, are further evidence of this marginal authorship. Judging from the number of African American authors, it would be easy to conflate street lit' with African American fiction. Refusing to reduce either genre, Vanessa Morris, a librarian and assistant professor at the College of Information Science and Technology at Drexel University, argues on her blog that "street lit is not race-based, but class-based [...]," and that,

Street Lit, as we consume it today, with stories primarily about Black and Latino peoples, is a historic happenstance, not a racially defining element of the genre. As a major contribution to the Street Literature realm, Street Lit historicizes contemporary ghetto life as an illustration of the looming presence of a lumpenproletariat in a hegemonic, patriarchal, capitalistic society [...]. (Morris, November $28^{\text {th }}, 2010$ )

6 Even so, this niche remains predominantly African American, and this article concentrates precisely on the specifically African American brand of street lit'. In my view, Morris's interesting opinion fails to acknowledge the financial profit that is often made from these stories of resistance against "hegemonic, patriarchal, capitalistic society." Indeed, Megan Sweeney clearly states how a "capitalist ideology undergirds" most of these books, whose protagonists' preoccupation with "making it" can be interpreted as a "rescripting" of the American Dream (Sweeney, 2010, 152). As such, although they do constitute a subculture of their own and partake of hip-hop culture, they cannot be identified as counterculture, and their eminently moralistic dimension -in keeping with the criminal memoir of today and yesterday-somehow undermines their subversive potential. Nelson George has observed that hip hop youth culture mixes a spirit of rebellion, identification with street culture and aggression with materialism (George, 1998, 155); just as hip hop culture has not escaped commodification, urban literature in its wake has also become commodified.

\section{Formulas and authenticity}

7 As in most popular fictional genres, street lit' displays an undeniable formulaic quality. Reporting on the topic in 2005 for Publishers Weekly, Essence magazine senior editor Patrik Bass summed up the formula in these words, "fast-paced, profanity-laced cautionary tales about modern urban life-which vary from drug deals gone bad to tough girls seeking redemption" (Bass, 2005). In this succinct yet effective phrasing of his own, Bass outlines the moralistic dimension of the books, and the authors themselves stress the importance of redemption. This further likens their books to the contemporary gang memoirs as well as to the XVII ${ }^{\text {th }}$ and XIX ${ }^{\text {th }}$ century criminal confessions. Indeed, Martha Vicinus has pointed out how "[b]y the late eighteenth century murders, rapes and arsons were most commonly narrated in the first person, emphasizing the wrongdoer's guilt and repentance" (Vicinus, 1974, 10). In the same 
manner, The Autobiography of Malcolm X, a thinly disguised subtext, demonstrates how prison allows time to reflect on one's past errors, and ultimately, to engage on the path to moral and social salvation. In the manner of the cultish 1970s mass-market pulp fiction, the authorial peritext of contemporary urban fiction often features confessions of sorts, emphasizing the redemptive experience of prison, and cautioning the reader against the risks of fast living. Undeniably, this "confessional gesture" was also lifted from the publishing practices of mass-market publishers such as Holloway House. ${ }^{6}$ Unsurprisingly, family and religion are repeatedly extolled as cardinal values, as in Shannon Holmes's introduction to Never Go Home Again,

it was never (nor will it ever be) my intention to have my novels become guidebooks on lawlesness [...]. Now that I have been blessed to become a successfully published author and my words are received by the masses, I have been given the power to communicate with the people, to have my voice heard and influence people's thoughts and opinions [...]. With that said, I feel a greater sense of responsibility, not only to myself, but to God and my readers. (Holmes, 2004, 1)

Perhaps even more pointedly-and less prophetically-after thanking God for "revealing to [her] that [...] strength is made perfect in weakness," (2002, vii) Vickie Stringer in her self-published best-seller and autobiographical novel, Let That be The Reason, cautions her readers in her afterword, "The events that have transpired in my life are very personal. I've exposed myself with the prayer that my life can be used as an example to warn others of the awful dangers of the drug Game" (Stringer, 2002, 243).

Knowing how Stringer recalled her experience as a drug dealer and madam, one is reminded of Defoe's ironic preface to Moll Flanders, wherein he pleaded for uncensored publication of his titillating novel, and which might have been appended to Stringer's novel,

Upon this foundation this book is recommended to the reader as a work

from every part of which something may be learned, and some just and

religious inference is drawn, by which the reader will have something

of instruction, if he pleases to make use of it.

All the exploits of this lady of fame, in her depredations upon

mankind, stand as so many warnings to honest people to beware of them,

intimating to them by what methods innocent people are drawn in,

plundered and robbed, and by consequence how to avoid them. (Defoe, 2003, 5)

10 In spite of these warnings, the cheap softcovers and the lurid cover art unmistakably scream "pulp fiction," a genre that traditionally relies on the familiarity of plots and characters.

11 Aside from their redemptive dimension, another essential and common characteristic of these books is their emphasis on authenticity. The authors-and publishers are quick to jump on the bandwagon-claim to offer the black experience, something that "can't be bought, faked, or learned in school," and invite the readers to follow the authors down to the "gritty and grimy undercarriage of society" which they have experienced first-hand (Holmes, 2004, 3-4). The authors' credentials are not degrees in creative writing but prison time and street wisdom, which youth culture values dearly. ${ }^{7}$ Once again we are reminded of pioneer Holloway House's marketing discourse and strategies: as evidenced in Justin T. Gifford's interviews of Wanda Coleman and Emory Holmes, the white-managed, black fiction mass-market publisher fed on, and exploited, the authenticity brought by Goines, Iceberg Slim or Odie Hawkins, to the extent that their authors felt compelled to give them ever more "grimy" texts. ${ }^{8}$ What might have begun as naively autobiographical writing resulted in the shaping, by white publishers, 
of the so-called "black experience." Certainly contemporary street lit' authors are also playing to these stereotypes to which they contribute.

Interestingly, while in the 1960s Holloway House sought to reach African American male readers, librarians and booksellers attest that more women are reading these stories than men-which can be accounted for by the fact that women are traditionally bigger readers, especially of fiction. ${ }^{9}$ Sweeney provides interesting testimonies on the variety of readings of urban fiction done by women prisoners of different ethnic backgrounds, "perform[ing] a range of readerly negotiations" (146), including the use of the texts as models with which to reflect upon their own lives, as wellas as escape literature. Although Sweeney does underline some of the virtues of the books-the making of new readers formerly unfamiliar with books, as well as their transformational, or redeeming, dimension-she also points to their potential danger. Indeed, she perceives the stories as strengthening "dominant ideologies and thereby help[ing] to create a pipeline to prison" (Sweeney, 2010, 171); although many narratives spin inspiring tales of empowerment, they also emphasize a common white judicial discrimination against ethnic minorities, corroborated by the statistics on prison populations, as suggested below. The limits of authenticity, however, are also brought home in prisons: many prison librarians now ban urban fiction, because they perceive it as glamorizing crime.

13 The question of readership, then, is inevitably brought forth, but unfortunately the data which would allow us to form an image, albeit hazy, is difficult to assess. ${ }^{10}$ Still, relying on different sources, we can reflect on the inferred, imagined and targeted readership.

Although editors are reluctant to admit that they might be "targetting" a particular readership with this type of fiction, still as scholar Susanne B. Dietzel acknowledges, "Afro American popular fiction is often grounded in the 'real' and 'immediate,' making explicit reference to the African American experience and issues of concern to the black community" (159). ${ }^{11}$ Librarian and blogger Megan Honig spontaneously defines "Contemporary street lit" as "a genre written by African American authors, intended for and marketed to an African American readership" (Honig, Dec 13, 2010). This definition, presumably based on her professional experience with teen readers, emphasizes an identification value within this fictional genre. One might add that the supposed readership is comprised of "the people in the streets," addressed by Vickie Stringer in her afterword to Let That be the Reason, urban readers who, again, can connect with the issues at stake (Stringer, 2002, 243). Moreover, several street lit' authors have been actively promoting and selling their books to prison inmates, whose taste for "real," authentic stories has been duly noted both by sociologists and prison librarians-incidentally Goines has become a superstar among prison inmates. ${ }^{12}$ Without drawing hasty conclusions, taking into consideration the hypothesis of identification value, statistics concerning the population in American prisons help to corroborate the hypothesis linking the inferred readership with the African American ethnic group: in 2003 the Black and Hispanic populations provided the majority of inmates sentenced to more than one year, while the percentile of inmates from racial or ethnic minorities remained stable between 1995 and 2003. ${ }^{13}$ One might reasonably infer that the authors were "targetting" these readers.

An unlikely source corroborating the idea that black fiction is predominantly read by black readers, are the findings of the U.S. District court for the Southern district of New 
York in the suit brought against Penguin by author Nadine Aldred in 2006; Aldred, a.k.a. Millenia Black, sued her publisher for marketing her novel The Great Pretender as black fiction, while it was devoid of racially determined characters and claimed to tackle the universal theme of marital infidelity. The findings declared that "on information and belief, novels classified and styled as African American fiction/ literature are typically purchased by a predominantly black, minority audience; not typically purchased by a white, majority audience," (my emphasis) and "marketed to a predominantly black, minority audience." ${ }^{14}$ Without addressing actual bookselling and publishing practices, these statements at least certainly attest to the validity of such claims in public opinion. And yet editors of urban fiction like to emphasize that black urban fiction has had the power to cross racial lines since the 1990s. Is this possibly due to the "vast appetite for 'black ghetto realness'" fuelled by the "authenticity discourse" (Quinn, 2000, 202) and the more general fascination-obsession?-with blackness? In 2000 Henry Louis Gates asserted his belief in Americans' capacity to "identify with black characters" and to see "the black experience" as "a metaphor for the larger human experience" (Arnold, 2001). Yet, he also very aptly pointed out that a racial cross-over for popular fiction was more easily attained through "wide distribution networks not limited solely to bookstores," thus stressing the specificity of this popular fiction. Indeed, if these books are repeatedly stacked in "African American" sections, it seems unlikely that a white customer will buy them from traditional bookstores. If we accept, with Morris, that this fiction is not race- but class-based, and acknowledge that culture or taste cultures, as defined by sociologist Herbert Gans, reflect and are affected by class, then the idea of a racial cross-over for these books becomes a possibility, in the absence of hard data.

\section{Strategies from the streets}

Better assessable are the publishing methods and distribution strategies of the authors. Many, if not most, of the authors under consideration began self-publishing their stories after experiencing multiple rejections by publishers. The transformation of L.A. fictionalized autobiographies into gang memoirs to accommodate publishers' demands (Metcalf), and the rise of Holloway House in the 1960s to make up for the contempt of West coast artists by the East Coast publishing establishment, tell the same story of agency. ${ }^{15}$ Surprisingly, self-publishing has not prevented some from becoming bestselling authors. Vickie Stringer, who self-published Let That Be The Reason after a sevenyear prison sentence, and claimed approximate sales of 100,000 copies of this first novel, is possibly the most famous and successful of these self-published authors. Since then, she has become a Simon \& Schuster author, publishing her books in their AfricanAmerican imprint, Atria Books. Other "rags to riches" stories abound, as authors reach for the American Dream in their own fashion: Dewitt Gilmore, a.k.a "Relentless Aaron," who wrote while serving a sentence for fraud, began publishing his books in 2003. Three years later he signed a "six figure deal" with St Martin's Press, and has since moved on to Simon \& Schuster's, publishing with G-Unit books, an imprint created by rapper 50 Cent. ${ }^{16}$ On the other hand, Stringer's fame and fortune have allowed her to diversify and become advisor both to prospective self-publishing authors, in her guidebook How to succeed in the Publishing Game (Triple Crown, 2004), and to mainstream editors. ${ }^{17}$ 
How do these self-published authors sell their books? Technology has greatly changed the game, Print on Demand technology now enables self-published authors to print their books cost-effectively: storage of large print runs thus becomes no longer necessary, and the writers avoid seeing hundreds of copies of their books gather dust in their homes. In addition, the Internet and mobile phone technologies are terrific means to create a "buzz," a particularly efficient marketing tool in the black community where personal recommendations are still greatly valued. As Stringer remarked to an interviewer, "Word of mouth is important in the African-American market. We're not always able to trust advertising" (Smith, 2004). The authors use websites both as a means of self-promotion, and as distribution channels. Furthermore, dozens of knowledgeable blogs have developed, created not only by fans, but also by public and prison librarians, which participate in the "legitimizing" of street lit' as instruments of literacy. ${ }^{18}$

For my very first sale, I approached a lady working in a hair salon. As she stood behind the chair, I held up my book and I asked her to buy it. I can remember her looking over the book without reaching for it. All the while my stomach was turning and my nerves were getting the best of me. The biggest fear with hand-tohand selling is the fear of rejection. Anyhow, I stood there, took a deep breath and trusted that my novel was worth the ten bucks I was charging. (Stringer, 2005, xiii)

Poise, determination, and economic wisdom-those are all essential qualities required for success in the selling of street lit', according to the self-appointed queen of the genre, Vickie Stringer. The above quote highlights some of the common characteristics of these self-publishers' sales strategies: books are initially sold hand-to-hand, in popular venues, and at the right price; selling directly on the street is usually the first step before web technology. These unconventional tactics often resemble the selling of rap tapes out of car trunks in the early 1980s...while also evoking another model, drug selling, in which many authors dabbled in their former lives. In the words of Monique Patterson, a senior editor at St Martin's Press-a Macmillan imprint-who was once in charge of Gilmore's/ Relentless Aaron's books, street-lit authors bring to the trade a "sort of hustler, business mentality" (Coates, 2006). And according to his agent, Gilmore claimed in 2006 to have sold some 200,000 books on his own (Kilgannon, 2006). Journalist Judith Rosen attributes part of their competence to the fact that these writers are street-wise, and understand that the more correctly they price their books, the better they will sell (Rosen, 2004).

Not all the marketing and distribution techniques, however, are new. As a matter of fact, whether consciously or not, these pulp authors-cum-publishers have relied on the non-conventional, yet traditionally used venues for African American publishing since the XIXth century, such as beauty salons, barber shops or churches, that are easily accessible for the Black community (Dietzel, 2004). They also make good use of prison networks, hinting at the existence of a rarely solicited readership that just might become a new niche for mainstream houses, and connecting with networks already explored in the 1970s by Goines and Beck's mass-market publisher. As Holloway House strove to appeal to an "audience of young, urban, and working-class African American men," it astutely sold its paperbacks in "newsstands, supermarkets, barbershops, and pool halls" (Dietzel, 2004, 163). In fact, the distribution techniques and strategies adopted and developed by these authors hail back to "olden times," and underline an intrinsic specificity of the African American book market: although published by a prestigious mainstream publisher, in the early $\mathrm{XX}^{\text {th }}$ century Charles Chesnutt quickly 
understood that his publisher was not seeking out the African American readership. He thus resolved to supplement Houghton Mifflin's marketing by developing channels of his own, organizing lecture tours and selling his works through extended family networks. ${ }^{19}$ In the 1920s and 1930s, itinerant bookseller Kathryn Johnson and poet Langston Hughes offered other examples of self-marketing, illustrating the importance of communities and non-traditional venues-churches, women's organizations-in a population that was largely overlooked by white publishers. ${ }^{20}$

The next phase for the more successful of these new fiction authors often includes the creation of their own imprints, to house their own production and that of other newcomers. Teri Woods and Vickie Stringer are possibly the best representatives in this group. After establishing Triple Crown Publications in 2002, Stringer signed bestselling author K'Wan (Foye), and in two years she succeeded in "stealing" one of Simon \& Schuster's start urban lit' writers, Shannon Holmes, offering him a five-book deal (Rosen, 2004). She also acts as literary agent to authors who attract the interest of bigger houses, and advises mainstream editors. ${ }^{21}$ In 2005 , $\mathrm{K}$ 'Wan also created his own imprint, Black Dawn Books, devoted to helping first authors.

21 Particularly amazing is the leverage that these new-style publishers exhibit: to issue a 25,000 or 50000 copy first print run no doubt requires a high degree of confidence. The explanation for such figures lies partly in the very structure of these imprints, and the reliance on cost-cutting technology. The importance of websites and POD cannot be over-emphasized.

\section{Going mainstream-commercial publishers borrowing marketing techniques "from below"}

Just as the rebellious hip hop culture of the 1980s became commodified in the 1990s, this black youth subculture has greatly been transformed, with many of these once selfpublished authors moving over to mainstream houses. Indeed, with the boom in African American fiction in the 1990s, small imprints specializing in urban fiction have bloomed. While some had existed in the market for some time, others diversified, trying to catch the next big thing: Strivers Row and One World Books at Random House, Harlem Moon at Doubleday, Dafina at Kensington and Atria at Simon \& Schuster are now well-known, their very names significantly related to African American culture, especially through the use of culturally-charged place names such as Strivers Row in Harlem..$^{22}$

The development of such imprints also testifies to the-belated-acknowledgement of the black consumer/ reader, who has been increasingly defined and identified by marketing studies and trendsetters since the mid-1990s. ${ }^{23}$ In 1998 a Target Market News survey on book buying and book reading by African Americans was actually requested by Anita Diggs, then editor at Warner Books (Labbe, 2000). The success of Sister Souljah's The Coldest Winter Ever (1999), and, in a less popular vein, of Terry Macmillan's best-selling Waiting to Exhale (1992), had taught publishers that there were black women readers to be reached, although the male readership remained somewhat more elusive. ${ }^{24}$ Elizabeth McHenry quotes the astonished vice-president and associate publisher of Scribner's in 1994, after the tremendous success of Terry Macmillan,

The African-American community, through bookstores, black wholesalers and organizations have an extremely successful way of popularizing new and up-and- 
coming black writers that doesn't exist in the white community [...]. Mainstream publishers didn't know it existed. They do now and have tapped into it. (quoted in McHenry, 2002, 302)

Simon \& Schuster, pragma
advice to budding authors,

As you've already begun to carve out your own niche in the literary industry, a larger publisher will see your work as a greater profit for less effort. You've already done the footwork and laid the foundation. A larger publisher will still work to promote your book and increase its popularity and sales, but will find much more ease in doing so because you've already jump-started the publicity and marketing process. (Stringer, 2004, 112)

Aside from their attempts to "cash in" on this lucrative trend, what is particularly striking is these mainstream publishers' adapting their marketing and selling techniques, and indeed, borrowing from these self-published authors' strategies, as they became increasingly aware of this market in the late 1990s. This included taking out advertisements in African American magazines and journals such as Black Issues Book Review or the woman's magazine Essence, or connecting with local and Internet book clubs in order to benefit from their address listings. They also continued to distribute through bookstores, although as African American fiction is usually classified in specific sections, there are doubts about the efficiency of this venue in reaching out to non-ethnic readers (Trachtenberg, 2006). Innovations began once these publishers progressively understood the specificity of this market. Although they will not readily admit to defining a "target market," their "core audience," to quote Atria editor Malaika Adero, is predominantly comprised of African Americans and Latinos, and the trick is to "start a buzz." As Anita Diggs, an editor at Ballantine Books, noted in 2001:

[...] the black community values recommendations from friends, family and community organizations much more than media hype. So we are always trying to find ways to plug into the community grapevine and start a buzz about a particular book. (Smith-Passariello, 2001)

These new ways include tie-in strategies with the hip-hop industry, taking out ads in music and culture magazines such as Vibe or The Source, rather than The New York Review of Books. Others, such as [S] Affiliated books, began by directly selling their books in record stores and clothes shops, with an accompanying CD (George L., 2000). Mainstream publishers' borrowing of marketing tricks from self-published authors in part demonstrates the extent to which extent African Americans are indeed being targeted. For one, they have now ascertained the efficacy of promoting on urban radio shows, concentrating on African American shows such as the nationally syndicated Tom Joyner Morning Show that once reportedly reached out to some seven million listeners, or through blogs and video advertising. In 2006, to promote a book by rapper C-Murder, Vibe Books at Kensington produced a 30-second video trailer that was circulated on YouTube. Since then, the trend of book-trailers has caught on. Connecting with hair, beauty salons and barber shops is another avenue being investigated by these larger imprints. For the launching of K'wan's Hood Rat in 2006, reportedly issued in a 50,000 copy print run, St Martin's Press organized parties at two 
carefully selected New York venues, one a literati lounge in a Harlem barber shop, the other a Brooklyn beauty salon, offering a mix of food, music and giveaways (Pride, 2006a). Some editors are even seriously considering distributing their books directly in prison, hoping to profit from the authors' experience and networks. ${ }^{26}$

By the mid-2000s, mainstream publishers seemed to have gauged the specificity of the African American market for popular fiction. Writing on the promotion of urban lit star author Teri Woods, who finally signed with a traditional publisher in 2006, Publishers' Weekly's Felicia Pride noted how the marketing campaign for Woods would encompass both "print advertising in traditional African-American publications, paid placements in magazines like People and subway advertising," and efforts to "reach out to multicultural communities" through a "nontraditional approach"-“cultivating relationships with major black organizations, such as the Association of African American Museums" (Pride, 2006b). ${ }^{27}$ The enormous sales figures of street lit' seem to attest to the success of these innovative marketing strategies: while Shannon Holmes's Bad Girlz (2003) allegedly sold 50,000 copies in the first three weeks of its release, K'wan's average sales for one book are estimated around 40,000 copies, and Vickie Stringer's second novel, published by Atria (Simon \& Schuster), was part of a two-book, six-figure deal (Foxworth, 2005; Coates, 2006; Smith, 2004).

\section{Conclusion}

The highly popular and lucrative genre of street lit' undeniably poses a series of literary, moral and sociological problems. Critics, editors and parents have repeatedly derided these books as "smut," deploring that young adults should read such stories of crime, sex and addiction (Chiles 2006). ${ }^{28}$ Yet others, including some public librarians, object that at least, young adults are now reading, and they are even advocating ordering young adult street literature for public libraries, as a way of encouraging teenagers to move on to other forms of literature. ${ }^{29}$ In his acknowledgements for The Diamond District, published by rapper 50-Cent's imprint, G-Unit, author Derrick R. Pledger offered a disclaimer against criticism of the genre, contending that he and his collaborators were "trying to combat the illiteracy epidemic plaguing American culture" (Pledger 2008, vii).

Another threat is the reductionist effect of these books on African American literature, which risks being ultimately limited to this mere best-selling fiction. Might not the stereotypical images of Blacks as loose women and drug-dealing, gun-toting gangsters deflect attention from the more demanding-legitimate? -works of Toni Morrison, Gloria Naylor or Percival Everett? This point is convincingly articulated in Everett's satire Erasure (2001), where the black protagonist, tired of seeing his manuscripts repeatedly turned down by publishers who find them "too white," and crushed when he realizes that an "idiotic, exploitative piece of crap" (213) will sell, decides to turn out an obscene street lit' title. In 2006, in a reaction to this debate, Malaika Adero reminded Publishers Weekly readers that,

[...] for the most part, publishing houses need a balance of big profit-makers-the commercially successful-and award-winners-the critically successful-to thrive. But both sides can and should benefit from reading (and observing the promotion behind) all kinds of fiction, especially from people who seem different from themselves. (Adero, 2006) 
31 Two points should be underlined: booksellers-and publishers-should make a clear distinction between contemporary African American "literature" and "fiction," and not jot them together under the category "African American." According to a 2008 Crisis article, some contemporary African American literature and fiction that is quite distinct from urban lit, is now being marketed with the same lurid covers, indicating a nefarious influence of such self-published titles on mainstream publishers (Ulen, 2008, 18-21). Secondly, an examination of the ways in which this fiction is actually read would require addressing the values transmitted by urban fiction, conjuring again the question of legitimate versus illegitimate culture. One might find that most readers do make a distinction between lowbrow and highbrow culture-to use categories on the verge of obsolescence-although all do not partake in this or that culture. ${ }^{30}$

Finally, the very status of these books seems problematic for the publishers as well as for critics, to judge from the diversity of categories under which they are listed: from young adult fiction, to genre fiction, to urban fiction... while the name street lit' is rejected as being "irrelevant." Malaika Adero blurs the boundaries between this "genre fiction" and "a long tradition in American literature of telling stories that document the sensibilities and experiences of: city dwellers, the impoverished, underground economies, outlaw culture, etc. and create myths out of the same". ${ }^{31}$ Certainly this argument holds in a debate on the tradition of street literature, yet there is no possible confusion between Vickie Stringer and Theodore Dreiser.

Still, leaving aside the popular versus highbrow debate, the publication of these books should be signaled for several reasons. First, it encourages innovations within the larger American publishing industry, foregrounding in a paradoxical yet complementary movement both the role of technology, and the importance of community networks and traditions. Furthermore, it substantiates the existence of a heretofore neglected African American, female and male, readership. As Charles Harris, founder of the mainstream black publishing imprint Amistad Press at Random House, noted in 2000, "The climate is right [...]. There's an increase in disposable income, a growing black middle class and more purchasing power" (Labbe, 2000). In turn, a growing demand for books about the African American experience was also to be noticed.

34 Finally, this "niche" provides an entry for newcomers who do not necessarily have the economic or cultural resources to enter this field of cultural production, leading us to reflect on the notion of entrepreneurship, or agency. In 1996, at the Fourth National Black Writers Conference held at Medgar Evers College in Brooklyn, several writers sounded a call for a change in American publishing, deploring the fact that in an overwhelmingly white establishment, the "canon" and more generally what should be published was not decided by African Americans. Poet and activist Amiri Baraka called the writers to build a "structure of "self-reliance and self-determination" (Phillip 1996). Indeed black publishers were still few in 1996, and the situation of black writers remained quite similar to that of their forefathers. As Scott McCracken writes, while by June 1996, some black writers were making the fiction bestseller lists of the New York Times,

African-Americans made up as little as 3.6 per cent of the publishing industry's workforce in 1994, compared with 21.9 per cent of the workforce in the NY area, the center of the US publishing industry. Writing by African-Americans has to negotiate a situation where, despite its popularity, the assertion of a black identity 
is at odds with the hegemonic culture and the structures of the culture industry.

(McCracken, 1998, 157)

$$
\begin{aligned}
& \text { agency and autonomy throughout entrepreneurial activity" }(2012,185) \text {. Still agency } \\
& \text { should not be mistaken for resistance: as long as these texts continue to play to the } \\
& \text { stereotypes of African Americans-and Latino Americans-in American society, and as } \\
& \text { their authors increasingly fall into the hands of "corporate gangsta" publishers, in the } \\
& \text { words of Daniel Marcou, these products of hip hop culture will inevitably lose their } \\
& \text { authenticity and subversive potential. }
\end{aligned}
$$

For Chris Jackson of The Atlantic, in 2011 the situation still had not significantly improved: in an acerbic obituary of African American literary agent Manie Barron, he suggested that his readers "walk the halls of a major book publishing company even today and count the black men [they] see in the halls-who aren't working in the mailroom-and see if [they] need all the fingers on even one hand" (Jackson C., 2011).

Although street lit' is not about to enter the African American canon, these authors, self-publishers and entrepreneurs were in their own ways building some form of "structure of self-reliance and self-determination." Interestingly, Stringer likens her experience to the great American Dream, thus giving books pride of place in modern world success stories:

From economics to just plain making dreams come true, self-publishing can be a vehicle for achieving the American Dream [. . .]. No one can dream your dream but you. And only you can see your dream in color. Now make it a reality by doing the necessary work. (Stringer, 2004, xii)

For Josephine Metcalf, Stringer's imprint "certainly confirms the possibility of black For Josephine Metcalf, stringer's imprint "certainly confirms the possibility of black should not be mistaken for resistance: as long as these texts continue to play to the stereotypes of African Americans-and Latino Americans-in American society, and as their authors increasingly fall into the hands of "corporate gangsta" publishers, in the authenticity and subversive potential.

\section{BIBLIOGRAPHIE}

\section{PRIMARY SOURCES}

Demand for trial by jury, United States District Court for the Southern district of New York, Nadine Aldred a/k/a Millenia Black, against Penguin Group, September 27, 2006, http:// www.onpointnews.com/docs/millenia.pdf. (last accessed on April 19, 2011).

HOLMES, Shannon Never Go Home Again, New York, Atria, 2004.

K'WAN, Hoodlum, New York, St Martin's Press-Griffin, 2005.

MACMILLAN, Terry, Waiting to Exhale, New York, Pocket Books, 1992.

SOULJAH, Sister The Coldest Winter Ever, New York, Simon \& Schuster, 1999.

STRINGER, Vicki, Let That be The Reason, Triple Crown, 2002.

---, How to Succeed in the Publishing Game, Triple Crown, 2004.

PRESS REVIEWS and ARTICLES

ANON, (1999), "HarperCollins Publishers Announces Acquisition of Preeminent African American Publisher, Amistad Press; Amistad Founder and Publisher Charles F. Harris to Join

Transatlantica, 1 | 2013 
HarperCollins," Business Wire, 27 October 1999, http://www.thefreelibrary.com/ HarperCollins+Publishers+Announces+Acquisition+of+Preeminent...-a056954506 (last accessed on February $\left.6^{\text {th }}, 2007\right)$.

ADERO, Malaika, “The Black Power of Fiction," Publishers Weekly, 10 July 2006, http:// www.publishersweekly.com/pw/by-topic/columns-and-blogs/soapbox/article/11140-the-blackpower-of-fiction.html (last accessed November 13th, 2013).

ARNOLD, Martin, “Making Books; Books by Blacks in Top 5 Sellers," New York Times Online, 26 July 2001, http://www.nytimes.com/2001/07/26/books/making-books-books-by-blacks-in-top-5sellers.html (last accessed on November 14th, 2013).

---, "Coming Soon: Paperbacks that Sound like Hip-Hop," New York Time, 21 September 2000, http://www.nytimes.com/2000/09/21/books/making-books-coming-soon-paperbacks-thatsound-like-hip-hop.html (last accessed on November 14th, 2013).

BASS, Patrik Henry, "The Bloom is off the Boom," Publishers Weekly, 11 July 2005, http:// www.publishersweekly.com/pw/by-topic/columns-and-blogs/soapbox/article/19260-the-bloomis-off-the-boom.html (last accessed on November 14th, 2013).

---, “New Jacket Required,” Publishers Weekly, 6 February 2006, http:// www.publishersweekly.com/pw/by-topic/columns-and-blogs/soapbox/article/8201-new-jacketrequired.html (last accessed on November 14th, 2013).

CHAVERS, Linda, “Five Figures: Black Book Publishing Today," Publishers Weekly, 12 December 2005, http://new.publishersweekly.com/pw/print/20051212/29847-five-figures-black-bookpublishing-today-.html (last accessed on May 5th, 2011).

CHILES, Nick, “Their Eyes Were Reading Smut," New York Times Online, 4 January 2006, http:// www.nytimes.com/2006/01/04/opinion/04chiles.html?_r=0 (last accessed on November $14^{\text {th }}$, 2013).

COATES, Ta-Nehisi Paul, "Hustle and Grow,“ Time, 9 October 2006, http://content.time.com/ time/magazine/article/0,9171,1543951,00.html (last accessed on November 14th, 2013).

DODSON, Angela P. “The Mainstreaming of Street lit,“ Black Issues Book Review, July-August, 2006, http://www.highbeam.com/doc/1G1-150583860.html (last accessed on November 14th, 2013).

FIALKOFF, Francine, “Street Lit Takes a Hit," Library Journal, 1 February 2006, http:// www.libraryjournal.com/article/CA6299839.html (last accessed on May 6th, 2011).

FLEMING, Robert, "Strivers Row imprint makes its debut," BookPage, 2001a, http:// bookpage.com/review/the-shirt-off-his-back/review, (last accessed on April 18 ${ }^{\text {th }}, 2011$ ).

---, “Black Book Bounty", Publishers Weekly, 10 December 2001 (b) http:// www.publishersweekly.com/pw/print/20011210/18783-black-book-bounty-.html (last accessed on May 5th, 2011).

FOXWORTH, R. Darryl, “Urban Legends," Baltimore City paper online, 14 September 2005, http:// www2.citypaper.com/news/story.asp?id=10505 (last accessed on November 14th, 2013).

GEORGE, Lynell, “Taking Pulp Fiction to the Streets," Los Angeles Times, November 2000, http:// articles.latimes.com/2000/nov/02/news/cl-45671/2 (last accessed on November 14th, 2013).

GERALD, Marc, Interview, Salon, 7 March 1997, http://www.salon.com/writer/marc_gerald/ (last accessed on November 14th, 2013).

GROSSBERG, Josh, “50 Cent in Da Books,” E! Online, 15 November 2005, http://fr.eonline.com/ news/51083/50-cent-in-da-books (last accessed on November 14th, 2013). 
HOLT, Karen, “Shades of Black Fiction," Publishers Weekly, 12 August 2003 http:// www.publishersweekly.com/pw/print/20031208/20996-shades-of-black-fiction.html (last accessed on November 14th, 2013).

JACKSON, Licia, "Black writers carve out niche," TheState.com, 28 February 2004, (last accessed on April 18th, 2011).

KILGANNON, Corey, "Street Lit with Publishing Cred: From Prison to a Four-Book Deal," New York Times, 14 February 2006, http://www.nytimes.com/2006/02/14/books/14rele.html? _r=1\&oref=slogin (last accessed on November 14th, 2013).

LABBE, Theola, "Black Books in the House," Publishers Weekly, 11 December 2000, http:// www.publishersweekly.com/pw/print/20001211/25598-black-books-in-the-house.html (last accessed on November 14th, 2013).

OGUNNAIKE, Lola, “Credentials for Pulp Fiction: Pimp and Drug Addict," New York Times, 25 March 2004, http://www.nytimes.com/2004/03/25/movies/credentials-for-pulp-fiction-pimpdrug-addict-for-novelist-donald-goines-dead-30.html?pagewanted=all\&src=pm (last accessed on November 14th, 2013).

PEARL, Nancy, "Lessons from the Old School: Street Lit Pioneers," Library Journal, 1 February 2006, http://www.libraryjournal.com/lj/ljinprintcurrentissue/865462-403/the_readers_shelflessons_from_the.html.csp (last accessed on April 17th, 2011).

PHILLIP, Mary-Christine, "Black Literature in the 90s," Black Issues in Higher Education, 16 May 1996, http://www.questia.com/library/1G1-18889560/black-literature-in-the-90s (last accessed on November 14th, 2013).

PRIDE, Felicia, “Count the Ways," Publishers Weekly, 11 December 2006a, http:// www.publishersweekly.com/pw/print/20061211/10360-count-the-ways.html (last accessed on November 14th, 2013).

---, “Thomas Builds a Black List at Hachette," Publishers Weekly, 20 October 2006b, http:// www.publishersweekly.com/pw/print/20061023/18222-thomas-builds-a-black-list-athachette.html (last accessed on November 14th, 2013).

REID, Calvin, “One World Launches Nikki Turner Book Line," Publishers Weekly, 27 April 2006a, http://www.publishersweekly.com (last accessed on February 6th, 2007).

---, "Smut and Reading: Debating Urban Fiction," Publishers Weekly, 21 May 2006b, http:// www.publishersweekly.com (last accessed on March 21th, 2007).

ROSEN, Judith, “Street Lit: Readers Gotta Have It,” Publishers Weekly, 13 December 2004, http:// new.publishersweekly.com/pw/print/20041213/38350-street-lit-readers-gotta-have-it-.html (last accessed April 18 $\left.{ }^{\text {th }}, 2011\right)$.

SMITH, Dinitia, "Unorthodox Publisher Animates Hip-Hop Lit," New York Times, 8 September 2004, http://www.nytimes.com/2004/09/08/books/08stri.html (last accessed on November 14th, 2013).

SMITH-PASSARIELLO, Carol, "New York Publishing's Black Pack - African American network," Black Issues Book Review, May 2001, http://www.thefreelibrary.com/ New+York+Publishing's+Black+Pack.-a075121822 (last accessed on April 19 ${ }^{\text {th }}, 2011$ ).

TRACHTENBERG, Jeffrey A., "Why book industry sees the world split still by race," The Wall Street Journal, 6 December 2006, http://www.post-gazette.com/pg/06340/744053-44.stm (last accessed on May 5th, 2011).

ULEN, E. N., "Sex and Lies," Crisis, Winter 2008, 115/1: 18-21. 
VALDES, Marcela, "What a Change in genre means to African Americans," Washington Post Book World, 18 June 2006, http://www.washingtonpost.com/wp-dyn/content/article/2006/06/15/ AR2006061501205.html (last accessed on April 19 ${ }^{\text {th }}, 2011$ ).

WEEKS, Linton “New Books in the Hood," The Washington Post, 31 July 2004, http:// www.washingtonpost.com/wp-dyn/articles/A29121-2004Jul30.html (last accessed on November $\left.14^{\text {th }}, 2013\right)$.

\section{SECONDARY SOURCES}

AGOSTO, Denise E. and HUGHES-HASSELL, Sandra, eds., Urban Teens in the Library: Research and Practice, The American Library Association, 2010.

ADERO, Malaika, electronic interview with the author, April 22, 2010.

BRAUN, Linda W., MARTIN, Hillias J. and URQUHART, Connie, Risky Business: Taking and Managing Risks in Library Services for Teens, American Library Association, 2010.

COLLISON, Robert, The Story of Street Literature: Forerunner of the Popular Press, Santa Barbara, ABCClio, 1973.

CHESNUTT, Charles W., To Be an Author, Letters of Charles W. Chesnutt, 1899-1905, ed. Joseph McElrath and Robert C. Leitz, Princeton, Princeton University Press, 1997.

COTTENET, Cécile, “Excavating original African American 'pulp fiction': W.W. Norton's Old School Books," in John Spiers, ed., The Culture of the Publisher's Series, vol 1, Authors, Publishers and the Shaping of Taste, London, Palgrave Macmillan, 2011, 141-55.

DAVEY, E., "Building a Black Audience in the 1930s: Langston Hughes, Poetry Readings, and the Golden Stair Press," in Print Culture in a Diverse America, ed. James P. Danky and Wayne A. Wiegand, Urbana, University of Illinois Press, 1998, 223-43.

DE CERTEAU, Michel, La Culture au pluriel, Paris, Seuil, Coll. Essais, 1993 [1974].

---, JULIA, Dominique and Jacques REVEL, “La Beauté du Mort”, in La Culture au pluriel, Paris, Seuil, Coll. Essais, 45-75.

DEFOE, Daniel, Moll Flanders, New York, W.W. Norton, 2003.

DIETZEL, Suzanne B., "The African American novel and popular culture," in Maryemma Graham et al, The Cambridge Companion to the African American Novel, Cambridge, Cambridge University Press, 2004, 156-68.

EVERETT, Percival, Erasure, Hanover, New Hampshire, University Press of New England, 2001.

FABIANI, Jean-Louis, Après la culture légitime, Objets, publics, autorités, Paris, L'Harmattan, 2007.

GANS, Herbert J., Popular Culture \& High Culture, Revised and updated edition, New York, Basic Books, 1999.

GATES, Henry Louis, Jr., “Harlem on Our Minds,” Critical Inquiry 24, autumn 1997, 1-12.

GEORGE, Nelson, Hip Hop America, New York, Viking, 1998.

GIFFORD, Justin D., “'Harvard in Hell': Holloway House Publishing Company, 'Players Magazine', and the Invention of Black Mass-Market Erotica: Interviews with Wanda Coleman and Emory 'Butch' Holmes II", MELUS, vol. 35, No. 4, The Bodies of Black Folk (WINTER 2010), 111-37, http:// www.jstor.org/stable/25759560 (last accessed on November $25^{\text {th }}, 2013$ ).

HONIG, Megan, Blog, http://www.meganhonig.com.

Hunter-Miller Group Report, “Black Gold,” 2001. http://www.huntermillergroup.com. 
KAMMEN, Michael, American Culture, American Tastes-Social Change and the $20^{\text {th }}$ Century, New York, Basic Books, 1999.

LASCH, Christopher, Culture de masse ou Culture populaire? translated by Frédéric Joly, Ed. Climats, 2001 [1981].

McCRACKEN, Scott, Pulp, Reading Popular Fiction, Manchester, Manchester University Press, 1998.

McHENRY, Elizabeth, Forgotten Readers, Recovering the History of African American Literary Societies, Durham and London, Duke University Press, 2002.

METCALF, Josephine, "From Rage to Rap and Prison to Print: Emergence of Gang Memoirs," European Journal of American Studies, 2009-2, http://ejas.revues.org/7651 (last accessed accessed on November $14^{\text {th }}, 2013$ ).

---The Culture and Politics of Contemporary Street Gang Memoirs, University Press of Mississippi, 2012. NISHIKAWA, Kinohi "Reading the Street: Iceberg Slim, Donald Goines, and the Rise of Black Pulp Fiction," Duke University, unpublished dissertation, 2010.

PLEDGER, Derrick, The Diamond District, New York, G-Unit, 2008.

QUINN, Eithne, "Black British Cultural Studies and the Rap on Gangsta," Black Music Research Journal, vol 20, 2, "European Perspectives on Black Music", Autumn 2000, 195-216.

SHEPARD, Leslie, The History of Street Literature: The Story of Broadside Ballads, Chapbooks, Proclamations, News-Sheets, Election Bills, Tracts, Pamphlets, Cocks, Catchpennies, and other Ephemera, Detroit, Singing Tree Press, 1973.

SWEENEY, Megan, Reading Is My Window: Books and the Art of Reading in Women's Prisons, Chapel Hill, The University of North Carolina Press, 2010.

VICINUS, Martha, The Industrial Muse: A Study of Nineteenth-Century British Working Class Literature, London, Croom Helm, 1974.

BLOGS

BOYD, K.C., Miss Domino, http://missdomino.blogspot.com. (last accessed on November $16^{\text {th }}$, 2013).

MARCOU, Daniel, Street Fiction, http://www.streetfiction.org (last accessed on January $5^{\text {th }}, 2012$ ). McCLELLAND, Susan, PHAT fiction http://phatfiction.blogspot.com (last accessed on November $\left.16^{\text {th }}, 2013\right)$.

MORRIS, Vanessa I., "Towards A Def'n 4 Street Lit”, November $28^{\text {th }}, 2010$, http:// www.streetliterature.com (last accessed on November 16th, 2013).

\section{NOTES}

1. Sister Souljah, born Lisa Williamson, is a rapper, activist and writer, often associated with the New York band Public Enemy. She came to public prominence in 1992, when an inflammatory remark following the Rodney King beatings was taken up by the Washington Post and President Bill Clinton in 1992, to discredit the blooming hip-hop movement.

2. On gang memoirs, see Josephine Metcalf, 2009 and 2012. In her studies of the Los Angeles genre, Metcalf describes these memoirs as "books that describe the ghettos and barrios and their gangbanging residents from first-person perspectives" (2009); she does specify that urban fiction books, although very similar, do not focus primarily on gang structures and culture. 
3. See Kinohi Nishikawa, "Reading the Street: Iceberg Slim, Donald Goines, and the Rise of Black Pulp Fiction," Duke University, unpublished dissertation, 2010. Goines's Daddy Cool (1974) is presumably the most widely read of his "crime fiction stories". A most prolific writer with a short five-year career, he published Dopefiend (1971), Whoreseon (1972), White Man's Justice, Black Man's Grief (1973), Never Die Alone (1974), which was adapted into a motion picture in 2004 starring rapper DMX. A list of Iceberg Slim's novels include Trick Baby: The Story of a White Negro (1967), Mama Black Widow: A Story of the South's Black Underworld (1969), or the sequel to Trick Baby, Long White Con: The Biggest Score in His Life! (1977).

4. On these pioneers, see Nancy Pearl, 2006.

5. The bulk of the Holloway House list was acquired in 2008 by Kensington Books.

6. On the issue of the confessional gesture, see Nishikawa, 2010, 169.

7. On the taste of youth for authenticity, see Gans, 1999, Kammen, 1999, N. George, 1998.

8. Wanda Coleman suggests that the search for more such stories, which Goines supposedly "stole" from other people (Gifford, 2010, 123), might have led to his death as he repeatedly returned to the dangerous street life to find fuel for his writing.

9. An African American bookseller in San Francisco stated that $90 \%$ of his urban fiction customers "were black professional women" (Calvin Reid, 2006b). See also Malaika Adero, electronic interview with the author, April 22, 2010.

10. Sociologist Megan Sweeney does provide some information in her study of prisoners' readings (2010), but her focus is strictly on women.

11. See Susanne B. Dietzel, 156-168; see also Cécile Cottenet, 2011.

12. See Jean-Louis Fabiani, 2007; see also Judith Rosen, 2004.

13. "U.S. Prison Population Approaches 1.5 Million" - Bureau of Justice Statistics News Release, 2010, accessed April 19, 2011, http://bjs.ojp.usdoj.gov. More specifically, statistics revealed the following proportions for inmates sentenced to more than one year: $44 \%$ were Black, $19 \%$ were Hispanic, and 35\% White.

14. Demand for trial by jury, United States District Court for the Southern district of New York, Nadine Aldred a/k/a Millenia Black, against Penguin Group, September 27, 2006, accessed April 19, 2011, http://www.onpointnews.com/docs/millenia.pdf.

15. See Wanda Coleman interviewed by Gifford, "The jazz musicians out here had the same complaints as the writers. West Coast artists have complained that it is so difficult, especially when you're black, to get attention from the East Coast establishment, and by the time they do notice you, if you're not dead, you're half dead. This is part of the cultural current that created this stuff." (124)

16. G-Unit was created under the impulse of 50-Cent's publicist, Marc Gerald, who was also coeditor of the Old School Books series for W.W. Norton between 1996 and 1998, and is now the literary agent of Nikki Turner and Teri Woods.

17. Malaika Adero, e-mail message to author, April 22, 2010.

18. See Megan Honig's blog at http://www.meganhonig.com. Honig is a specialist in Young Adult Materials at the NYPL; K.C. Boyd, at http://missdomino.blogspot.com. Another blog, http:// www.streetfiction.org was created by Daniel Marcou, a Corrections Librarian. PHAT Fiction created by Susan McClelland, Reader's Advisor at the Evanston Public Library (http:// phatfiction.blogspot.com/).

19. Charles W. Chesnutt sold his books through E. French Tyson, a distant relative, as documented in his correspondence (Chesnutt, 1997, 136, 138, 234).

20. See Elizabeth McHenry, 2002, 299-301; Elizabeth Davey, 1998.

21. Malaika Adero, e-mail message to author, April 22, 2010.

22. See Carol Smith-Passariello, 2001; Robert Fleming, 2001a and 2001b.

23. On the presence of black imprints and editors, see Linda Chavers, 2005. 
24. Waiting to Exhale remained on the Wall Street Journal best-seller list for 36 weeks. See Jeffrey A. Trachtenberg, 2006.

25. Hunter-Miller Group Report, "Black Gold", 2001. http://www.huntermillergroup.com. The Hunter-Miller Group is a marketing consulting group specializing in the African-American market.

26. Malaika Adero, e-mail message to the author, April 22, 2010. Adero admitted that they had asked Vickie Stringer for advice on this particular point.

27. Teri Woods, a former paralegal, had long refused to join a bigger imprint, failing to see the financial gain. See Judith Rosen, 2004.

28. On the polemics, see also Marcela Valdes, 2006.

29. See librarians' guides such as Denise E. Agosto and Sandra Hughes-Hassell,2010, and Linda W. Braun, Hillias J. Martin and Connie Urquhart, 2010; see also Francine Fialkoff, 2006.

30. Sweeney's 2010 findings seem indeed to warrant this idea.

31. Malaika Adero, e-mail to the author, April 22, 2010.

\section{RÉSUMÉS}

Apparue au milieu des années 1990, une fiction populaire, essentiellement africaine américaine et alternativement appelée «street lit'« ou «hip-hop literature», a considérablement fait augmenter le nombre de titres «noirs » vendus aux Etats-Unis. Les auteurs, souvent d'anciens membres de gangs ou prisonniers, suivaient les traces des auteurs-cultes de pulp fiction des années 1970, Donald Goines, auteur notamment de Daddy Cool et Whoreson, et Robert Beck, alias Iceberg Slim, l'auteur du célèbre - et autobiographique - Pimp.

Cette fiction urbaine, ancrée dans la communauté noire, brode à l'envi sur les thèmes du sexe, de la drogue, des armes et de l'argent, tout en mettant en lumière l'importance de la rédemption pour ses auteurs - et sans doute également, ses lecteurs potentiels.

Les ventes extraordinaires, atteignant pour certains titres 100000 exemplaires en quelques semaines, attirèrent bientôt les éditeurs mainstream, qui s'empressèrent de proposer des contrats fort lucratifs aux auteurs qui jusque là s'auto-publiaient. En créant de nouvelles collections spécialisées, ces éditeurs allaient rapidement déplacer ce phénomène depuis la marge vers un centre à la fois éditorial et culturel.

Par son ampleur, ce phénomène d'édition mérite que l'on s'y attarde; objet de culture populaire ou de culture de masse, il est véritablement à l'intersection de l'histoire de l'édition et des études Africaine Américaines. Cet article se propose d'analyser les pratiques de ces auteurs à la lumière du concept d'agency, et d'explorer tout particulièrement les stratégies de marketing et de vente, à la fois des auteurs puis de leurs éditeur, afin de juger de leur aspect novateur.

Emerging in the mid-1990s, Street lit', or hip-hop literature undeniably contributed to the boom in African American fiction of the late 20th century. The authors of the genre, many of whom are former gang members or convicts, followed in the steps of the best-selling pulp writers of the 1970s Donald Goines (Whoreson, Daddy Cool) and Robert Beck aka Iceberg Slim (Pimp).

This urban literature can be loosely characterized as formulaic stories set in the black community, revolving around sex, drugs, guns and cash; yet they also emphasize redemption and can be read as cautionary tales for the young. With some titles selling up to 100000 in record time, this phenomenon was bound to move from the margins to the center, and indeed 
mainstream publishers soon entered the market, proposing lucrative contracts to the selfpublished authors, and creating or expanding specialized black-oriented imprints.

Assessment of this trend allows for observation of the intersection of book history and "African American" studies. This paper endeavors to show how the concept of agency can aptly be used to describe self-publishing, which many authors of street lit' resort to. Finally, this paper will look into the marketing and selling strategies developed by publishers as a consequence of the specific ethnic and sociological background of both authors and readers.

\section{INDEX}

Keywords : African American street literature, self-publishing, niche publishing, marketing

\section{AUTEUR}

CÉCILE COTTENET

LERMA EA853, Aix Marseille Université 